Saudi Journal of Economics and Finance

Abbreviated Key Title: Saudi J Econ Fin ISSN 2523-9414 (Print) |ISSN 2523-6563 (Online) Scholars Middle East Publishers, Dubai, United Arab Emirates Journal homepage: http://saudijournals.com/sjef/

Original Research Article

\title{
Community Political Participation in Local Leaders Election 2013, Pulang Pisau Regency
}

Muhammad Abdus Salim*

Master Program of Government Science, Lambung Mangkurat University, Banjarmasin, Indonesia

\author{
DOI: $10.36348 /$ sjef.2019.v03i11.005 $\quad$ | Received: 09.11.2019| Accepted: 15.11.2019| Published: 19.11 .2019 \\ *Corresponding author: Muhammad Abdus Salim
}

\section{Abstract}

Community political participation is a form of the realization of a demoralized state. Political participation not only appears in the General Election (Election) but also in the Locaal Leaders Election (Pemilukada). This study aims to describe the political participation of Pemilukada in Pulang Pisau Regency in 2013. An explanatory quantitative approach was used in the study. The collection technique is done through interviews and questionnaires. The results of the study describe that community political participation in the post-conflict local election in Pulang Pisau District in 2013 was influenced by three factors; individual, social, and behavioral characteristics. put forward based on the results of the research respondents' answers, to illustrate political participation conventionally and non-conventionally.

Keywords: Pemilukada, political participation, voter characteristics.

Copyright @ 2019: This is an open-access article distributed under the terms of the Creative Commons Attribution license which permits unrestricted use, distribution, and reproduction in any medium for non-commercial use (NonCommercial, or CC-BY-NC) provided the original author and source are credited.

\section{INTRODUCTION}

Elections in Indonesian politics are a political instrument that is carried out every five years. Elections are conducted to elect legislative and executive members. The elected legislative members in the election consist of members of the central legislature which in the Indonesian constitution are called Regional Representative Council (DPRD) at Provincial and Regency/City. While in the executive election context, the people are given the opportunity to elect their leaders in the executive branch, the President, the Governor and the Regent/Mayor [1].

The granting of political rights and freedom to the Indonesian people today is inseparable from the political reform agenda that had previously been championed by the Indonesian people, where before 1998 the political rights of the people were often discriminated against and made only as supplementary formal conditions. Meanwhile, in reality the people are not given full political rights to select their future leaders, criticize policies, until the closing of dialogical spaces to channel people's aspirations and interests.

The level of citizen participation on the implementation of the electoral process can be seen based on the awareness of the public in the process and stages of the election. The government encourages increased citizen participation with the aim of being able to play an active role in democratic activities and processes. Participation is a measure in the development of community democracy and the political life system of the nation and state. Based on this, participation in political activities, both formally and informally, can be realized in the form of supervisory actions in the process of organizing elections.

Citizens who only consist of simple societies tend to be underestimated in political processes. Political participation in relation to democracy influences people's trust in the course of a government. Each member of the community understands and has an interest in what is their decision in the election, so that a public government official is very dependent on the judgment of the people who chose him.

Fulfillment of the political rights of citizens in elections is to have freedom of opinion and assembly, as written in the 1945 Constitution article 28: freedom of association and assembly to express thoughts through oral and written and so forth stipulated by law. Political participation is one of the fundamental principles in the concept of good government, so that various groups put political participation as one of the initial strategies that initiated reforms in 1998 [2]. As a manifestation of people's sovereignty is political participation in the election of local leaders and this is very fundamental in the democratic system. if the community has a high level of participation, the process of political life and 
the practice of democratization in Indonesia will run well.

Huda's research [3] stated "the response of the village community in participating in the Local Leaders Election (Pemilukada) in 2012, it can be concluded that their response was quite high in participating. However, their participation is high because it is caused by money politics, so Tegalharjo people are more likely to be vulnerable to money politics [3]. Thus, this article aims to describe the various obstacles related to the political participation of Pulang Pisau community in the Pulang Pisau District Election in 2013.

\section{METHODS}

This research uses a quantitative descriptive approach with a case study method. The type of research used is explanatory research, which is a study that highlights between variables and tests of hypotheses that have been formulated. The type of research used is associative (causal relationship), which aims to determine the relationship between two or more variables [4]. Statistical analysis was used to find out the factors that influenced the political participation of the community in the post-conflict local election in Pulang Pisau Regency, Central Kalimantan.

Research by the method requires a detailed, indepth, comprehensive study of certain objects that are usually relatively small over a certain period of time, including the environment [5]. This study illustrates the factors that influence community participation related to political participation in the Regional Election. The results of the study reveal the factors that influence political participation conventionally and unconventionally, so that a description of public behavior as a form of participation in the Regional Head General Election is obtained, as well as efforts that can be applied to increase public political participation.

The research location was conducted in eight 8 (eight) Districts and 91 Villages located in Pulang Pisau Regency, Central Kalimantan Province. The determination of the sample is to use the random method (random) in each village. The number of samples determined in this study was 72 samples, with the following criteria:

- In 2013, they were old enough and had the right to vote.

- Residing in Pulang Pisau Regency.

Data collection was performed using data collection techniques with observation methods and survey techniques using a questionnaire. Research analysis was collected based on the results of the questionnaire which is nominal data (score value) then processed using product moment correlation analysis [6].

\section{RESULTS AND DISCUSSION}

The idea of the direct post-conflict local election is basically a further process of a strong desire to improve the quality of democracy in the regions that have already begun. Democracy is intended to achieve other goals, including the realization of individual essential rights; there is an opportunity to determine the position of the individual, and the existence of welfare. So far, democracy is understood as a form of direct election to fill public or political office. In general, in filling the position of regional head using two channels, the first is through the political party channel and the second path is through an independent candidate or what is commonly called the individual channel.

Voters choose candidates who best represent the policy position and candidates who can maximize their votes are supported in the study of voting behavior in Pulang Pisau. Political issues in the form of development became their hope after they got their information and simple analysis when they compared their regions with other regions, namely Pulang Pisau District.

\section{Sociological approach}

Regional ties are very strong in the behavior of electing regional heads in the Pulang Pisau Regency community. This happened because of social contact between residents in Pulang Pisau Regency which are close to Pulang Pisau region, especially regarding the development of the area when it was led by the original regional head of Pulang Pisau residents and Pulang Pisau residents who eventually formed a mutual understanding of the Pulang Pisau community in choosing their regional heads.

\section{- Psychological approach}

Pulang Pisau people, who for the most part have traditionally originated, lived, settled, and made a living in Pulang Pisau and its surrounding areas have strong psychological ties with the region, not with the candidates to be elected. They identify themselves with the area they have lived for generations. In addition, being led by candidates from their own regions (Pulang Pisau and surrounding areas) reflected their pride even though they did not yet know the figures to be nominated.

\section{- Rational choice approach}

Society is more rational by assessing contemporary issues, namely regional development. The community considers that being led by candidates from their own regions (Pulang Pisau and surrounding areas) development can be realized more quickly because by being led by the regional head of his own area, the regional head knows more about the weaknesses and strengths of his area compared to the regional head from other regions. 
Efforts to increase voter participation, according to the authors, can be traced operationally from several conditions around abstentions and integrating them to find common ground operationally, namely:

- Conditions that are the problem / causes of lack or low voter participation.

- The line of participation in the segmentation of vulnerable voters: novice voters, swing voters, elderly voters, those who lack access to information, the "abstentions".

- Active stakeholder holders, namely "who has an interest in voter participation".
If the people feel that their affairs are fulfilled with election activities, then they feel close to the postconflict local election and are willing to participate in the post-conflict local election. In this condition, the treatment that can be done is to bring the issue of local election closer to the affairs and interests of the people. With regard to political participation in the context of post-conflict local elections in Pulang Pisau Regency, it is presented based on validation tests. The validation test used in this study is the item validation test, which tests the validation of the quality of the items. Based on the product moment correlation coefficient from the calculation results, it can be seen that the question items on the questionnaire are valid if they have a correlation coefficient value greater than $0.3(\geq 0.3)$. Validity data test can be seen in the following table:

Table-1: Validity and Reliability Test Results

\begin{tabular}{|c|c|c|c|c|c|}
\hline \multirow{2}{*}{ Variable } & \multirow{2}{*}{ Item } & \multicolumn{2}{|c|}{ Validity } & \multicolumn{2}{|c|}{ Reliability } \\
\hline & & $\mathbf{R}$ & Description & Spearman Brow & Description \\
\hline \multirow{4}{*}{ Individual Characteristics } & $\mathrm{X} 1.1$ & 0.847 & Valid & \multirow{4}{*}{0.735} & \multirow{4}{*}{ Reliable } \\
\hline & $\mathrm{X} 1.2$ & 0.867 & Valid & & \\
\hline & $\mathrm{X} 1.3$ & 0.679 & Valid & & \\
\hline & $\mathrm{X} 1.4$ & 0.614 & Valid & & \\
\hline \multirow{3}{*}{ Social Characteristics } & $\mathrm{X} 2.1$ & 0.928 & Valid & \multirow{3}{*}{0.759} & \multirow{3}{*}{ Reliable } \\
\hline & $\mathrm{X} 2.2$ & 0.775 & Valid & & \\
\hline & $\mathrm{X} 2.3$ & 0.802 & Valid & & \\
\hline \multirow{3}{*}{ Election Behavior } & $\mathrm{X} 3.1$ & 0.476 & Valid & \multirow{3}{*}{0.740} & \multirow{3}{*}{ Reliable } \\
\hline & $\mathrm{X} 3.2$ & 0.714 & Valid & & \\
\hline & $\mathrm{X} 3.3$ & 0.763 & Valid & & \\
\hline \multirow{10}{*}{ Political Participation (Y) } & P.1 & 0.537 & Valid & \multirow{10}{*}{0.845} & \multirow{10}{*}{ Reliable } \\
\hline & P.2 & 0.491 & Valid & & \\
\hline & P.3 & 0.470 & Valid & & \\
\hline & P. 4 & 0.499 & Valid & & \\
\hline & P.5 & 0.467 & Valid & & \\
\hline & P.6 & 0.677 & Valid & & \\
\hline & P.7 & 0.564 & Valid & & \\
\hline & P.8 & 0.429 & Valid & & \\
\hline & P.9 & 0.582 & Valid & & \\
\hline & P.10 & 0.821 & Valid & & \\
\hline
\end{tabular}

Based on the table, it shows that all question items on the research instrument are valid because the correlation coefficient value is greater than 0.3 . While the reliability test shows that all research variables have coefficient values greater than 0.6 so that all factors can be declared reliable. Correlation analysis proposed in this study is to measure the relationship of individual characteristics, social characteristics, and electoral behavior with political participation in society in the Pulang Pisau District Election process, using the Pearson Product Moment correlation test.
The Relationship between Individual Characteristic Factors (Karakteristik Individu) and Political Participation (Partisipasi Politik) in the Community in the Pulang Pisau District Election Process

Correlation testing (relationship) between individual characteristic factors and political participation in society in the Pulang Pisau District Election Process can be seen in the SPSS output as follows: 
Table-2: Correlation Test Results of Individual Characteristics with Political Participation

\begin{tabular}{|ll|r|r|}
\hline \multicolumn{3}{|c|}{ Correlations } \\
\hline & $\begin{array}{c}\text { Partisipasi } \\
\text { Politik }\end{array}$ & $\begin{array}{c}\text { Karakteristik } \\
\text { Individu }\end{array}$ \\
\hline Partisipasi Politik & Pearson Correlation & 1 & $.806^{* *}$ \\
& Sig. (2-tailed) & 72 & .000 \\
& $\mathrm{~N}$ & $.806^{* \star}$ & 72 \\
\hline Karakteristik Individu & Pearson Correlation & .000 & 1 \\
& Sig. (2-tailed) & 72 & 72 \\
$\mathrm{~N}$ & \\
\hline
\end{tabular}

Based on the results of these tests, it can be seen that the Pearson correlation coefficient is 0.806 with a significant value of 0.000 . These results indicate that there is a close relationship between individual characteristic factors and political participation in the community in the Pulang Pisau District Election Process, because the significant value is less than 0.05 . The level of closeness of the relationship generated based on the correlation coefficient value of 0.806 shows that the individual characteristic factors with political participation in the community in the Pulang Pisau District Election Process is to have a very high relationship category, because it is in the interval of coefficient values of $0.800-1,000$. Based on the results of the correlation analysis, the first hypothesis (H1) which states that: There is a close relationship between individual characteristic factors and political participation in society in the Pulang Pisau District Election process is accepted.

The relationship between social characteristics (Karakteristik Soosial) factors and political participation (Partisipasi Politik) in society in the Pulang Pisau District Election process

Correlation testing (relationship) between social characteristics factors and political participation in society in the Pulang Pisau District Election Process can be seen in the SPSS output as follows:

Table-3: Hasil Uji Korelasi Karakteristik Sosial dengan Partisipasi Politik

\begin{tabular}{|ll|r|r|}
\hline \multicolumn{3}{|c|}{ Correlations } \\
\hline & \multicolumn{1}{|c|}{$\begin{array}{c}\text { Partisipasi } \\
\text { Politik }\end{array}$} & $\begin{array}{c}\text { Karakteristik } \\
\text { Sosial }\end{array}$ \\
\hline Partisipasi Politik & Pearson Correlation & 1 & $.758^{* \star}$ \\
& Sig. (2-tailed) & & .000 \\
& $\mathrm{~N}$ & 72 & 72 \\
\hline Karakteristik Sosial & Pearson Correlation & $.758^{\star *}$ & 1 \\
& Sig. (2-tailed) & .000 & 72 \\
$\mathrm{~N}$ & 72 & \\
\hline
\end{tabular}

Based on the results of these tests, it can be seen that the Pearson correlation coefficient is 0.758 with a significance of 0.000 . These results indicate that there is a close relationship between social characteristics factors and political participation in society in the Pulang Pisau District Election Process. The level of closeness of the relationship generated based on the value of the correlation coefficient of 0.758 indicates a high category of relationships, because it is in the interval of coefficient values of $0.600-0.800$. Based on the results of the correlation analysis, the second hypothesis (H2) which states that: There is a close relationship between social characteristics factors with political participation in the community in the Pulang Pisau District Election process, is accepted.

The relationship between the factors of electoral behaviour (Perilaku Pemilihan) with political participation (Partisipasi Politik) in the community in the Pulang Pisau District Election process

Correlation testing (the relationship) between the factors of electoral behavior with political participation in the community in the Pulang Pisau District Election Process can be seen in the SPSS output as follows: 
Table-4: Correlation Behavior Test Results with Political Participation

\begin{tabular}{|c|c|c|c|}
\hline \multicolumn{4}{|c|}{ Correlations } \\
\hline & & $\begin{array}{l}\text { Partisipasi } \\
\text { Politik }\end{array}$ & $\begin{array}{l}\text { Perilaku } \\
\text { Pemilihan }\end{array}$ \\
\hline Partisipasi Politik & $\begin{array}{l}\text { Pearson Correlation } \\
\text { Sig. (2-tailed) } \\
\mathrm{N}\end{array}$ & $\begin{array}{r}1 \\
72\end{array}$ & $\begin{array}{r}.557^{\star *} \\
.000 \\
72\end{array}$ \\
\hline Perilaku Pemilihan & $\begin{array}{l}\text { Pearson Correlation } \\
\text { Sig. (2-tailed) } \\
\mathrm{N}\end{array}$ & $\begin{array}{c}.557^{\star \star} \\
.000 \\
72\end{array}$ & $\begin{array}{r}1 \\
72\end{array}$ \\
\hline
\end{tabular}

Based on the results of these tests, it can be seen that the Pearson correlation coefficient is 0.557 with a significant value of 0,000 . These results indicate that there is a close relationship between the factors of electoral behavior with political participation in the community in the Pulang Pisau District Election Process, because the significant value is less than 0.05 . The level of closeness of the relationship produced based on the correlation coefficient value of 0.557 shows that the electoral behavior factor with political participation in the community in the Pulang Pisau District Election Process is to have a sufficient relationship category, because it is in the interval of coefficient values of 0.400 to 0.600 . Based on the results of the correlation analysis, the third hypothesis (H3) which states that: There is a close relationship between the factors of electoral behavior with political participation in society in the Pulang Pisau District Election process, is accepted.

Elections are recognized globally as an arena for forming representative democracy and for periodic change of government. According to the theory of minimalist democracy (Schumpetrian), elections are an arena that facilitates competition (contestation) between political actors to gain power; political participation of the people to make choices; liberalization of civil and political rights of citizens [7]. Democracy also stipulates that elections are an opportunity for opposition parties and the people to run a check and balance mechanism against the ruling party. Although many people consider this conception of democracy to be minimalist, the practice of minimalist democracy has formed a system of determining / filling public offices in all democratic countries. This means that elections have been institutionalized and have become a universal mechanism in the political system in a democratic country [8].

Community political participation is a form of the realization of a demoralized state. Countries without political participation from society tend to be authoritarian and centralistic. Political experience during the New Order shows the arbitrariness of political decision makers in every policy formulation and program planning. As a result, the policies or decisions often do not fit the needs of the community.
Community political participation is a form of selfgiving in the form of participation, presence, ideas, and involvement in policy formulation and self-giving in supervision when the policy is to be implemented.

There are three main reasons why community participation has a very important nature $[9,10]$. First, community participation is a tool for obtaining information about the conditions, needs and attitudes of the local community, without which development programs and projects fail. Second, people trust the project or program more if they feel involved in the preparation and planning process, because they know more about the ins and outs of the project and will have a sense of ownership of the project. Third, the assumption arises that it is a democratic right if people are involved in the development of their own communities. It can be felt that they also have the right to give advice in determining the type of development carried out.

The political participation of the community in the General Election also determines the direction and progress of a nation. The quality of political participation will be highly determined whether all people who have fulfilled the mandatory vote can vote, whether the community is given access or ease in choosing and whether the community can choose a quality leader based on confidence and trust in the chosen candidate. The actual election problem is not only limited because the technical process is often encountered many violations but the main problem is the outcome or substance of the election is still far as expected. The real outcome expected from elections is to give birth to the ideal leader.

In the context of post-conflict local election participation that occurred in Pulang Pisau Regency is divided into two, namely conventional and nonconventional participation. The conventional participation of the Pulang Pisau Regency community in the 2013 Pemilukada was based on individual attitudes and actions of the voters, which consisted of the following: 


\section{Use of Voting Rights}

The use of voting rights from voters is a direct action to come to the polling station (TPS) and vote after someone is registered as a voter. Based on the opinion of research respondents, the data obtained as the following table.

Table-5: Conventional Political Participation of Communities in the Use of Voting Rights

\begin{tabular}{|l|c|c|c|}
\hline \multirow{2}{*}{ Description } & \multicolumn{2}{|c|}{ Answer } & \multirow{2}{*}{ Total } \\
\cline { 2 - 3 } & Yes & No & \\
\hline Total (respondents) & 70 & 2 & 72 \\
\hline Percentage (\%) & 97.22 & 2.78 & 100.00 \\
\hline
\end{tabular}

Based on this table it can be seen that the majority of respondents used their voting rights in the 2013 General Election, as many as 70 people $(97.22 \%)$. There are 2 respondents $(2.78 \%)$ who do not use their voting rights, this can be understood given the character of the region and individual voters who have a busy and activities that cannot be abandoned such as farming in distant places, or traveling. These results illustrate that in general the people in Pulang Pisau Regency have enthusiasm in using voting rights in the General Election.

\section{Participation in campaign activities}

Participation in political campaign activities by community members is to take action or be active in campaign activities organized by political parties. The campaign activity in Pulang Pisau Regency in this case is mass gathering in a certain place by presenting the political programs of certain parties. Based on the opinion of research respondents, the data obtained as the following table.

Table-6: Conventional Political Participation of Society in Participation in Campaign Activities

\begin{tabular}{|l|c|c|c|}
\hline \multirow{2}{*}{ Description } & \multicolumn{2}{|c|}{ Answer } & \multirow{2}{*}{ Total } \\
\cline { 2 - 3 } & Yes & No & \\
\hline Total (respondents) & 43 & 29 & 72 \\
\hline Persentage (\%) & 59.72 & 40.28 & 100.00 \\
\hline
\end{tabular}

Based on this table it can be seen that the majority of respondents participated in campaign activities in the 2013 Pemilukada, as many as 43 people $(59.72 \%)$. There were 29 respondents $(40.28 \%)$ who did not participate in campaign activities. This is based on the characteristics of respondents, most of whom are housewives, while men are traders.

\footnotetext{
Participation in the Political Discussion Forum for the Implementation of the 2013 Local Leaders Election

Participation in political campaign activities by community members in the political discussion forum at the post-conflict local election is to conduct activities directly in expressing opinions in a forum. Based on the opinion of research respondents, the data obtained as the following table.
}

Table-7: Conventional Political Participation of the Community in Participation in Political Discussion Forums in the Context of the Implementation of the 2013 Local Leaders Election

\begin{tabular}{|l|c|c|c|}
\hline \multirow{2}{*}{ Description } & \multicolumn{2}{|c|}{ Answer } & \multirow{2}{*}{ Total } \\
\cline { 2 - 3 } & Yes & No & \\
\hline Total (respondents) & 28 & 44 & 72 \\
\hline Persentage (\%) & 38.89 & 61.11 & 100.00 \\
\hline
\end{tabular}

Based on this table, it can be seen that the majority of respondents did not participate in the political discussion forum in the context of the implementation of the 2013 General Election, as many as 44 people $(61.11 \%)$. There were 28 respondents (28.89\%) who participated in campaign activities. This illustrates that most people do not yet understand the meaning of involvement in a discussion forum so that they only tend to be listeners and recipients of information from the results of discussions from several forums so that they make it as input for knowledge about the politics of Pemilukada.

\section{Registered as a member of a particular political community}

The role of the political community in the form of self-registration as a member of a particular political community is to express themselves in the form of direct support, namely to become a member of the political community of a particular candidate pair. Based on the opinion of research respondents, the data obtained as the following table.

Table-8: Conventional Political Participation of Communities Registered as Members of Specific Political Communities

\begin{tabular}{|l|c|c|c|}
\hline \multirow{2}{*}{ Description } & \multicolumn{2}{|c|}{ Answer } & \multirow{2}{*}{ Total } \\
\cline { 2 - 3 } & Yes & No & \\
\hline Total (respondents) & 31 & 41 & 72 \\
\hline Persentage (\%) & 43.06 & 56.94 & 100.00 \\
\hline
\end{tabular}

Based on this table it can be seen that the majority of respondents are not registered as members of a particular political community, as many as 41 people $(56.94 \%)$. This illustrates that they consider that being a member of a particular political community does not become important in participating politics.

\section{Submitting a statement of attitude in response to a political policy}

Community participation in submitting an attitude in responding to a political policy is an attitude that is taken in accordance with the income and community consideration of policies related to the implementation of politics, giving rise to a direct or indirect response. Based on the opinion of research respondents, the data obtained as the following table. 
Table-9: Conventional Political Participation of Society in Submitting Statement of Attitude in Responding to a Political Policy

\begin{tabular}{|l|c|c|c|}
\hline \multirow{2}{*}{ Description } & \multicolumn{2}{|c|}{ Answer } & \multirow{2}{*}{ Total } \\
\cline { 2 - 3 } & Yes & No & \\
\hline Total (respondents) & 16 & 56 & 72 \\
\hline Persentage (\%) & 22.22 & 77.78 & 100.00 \\
\hline
\end{tabular}

Based on this table it can be seen that the majority of respondents did not directly convey a statement of attitude in responding to a political policy, namely as many as 56 people $(77.78 \%)$. This illustrates that most people do not understand the political policies that have been set so that they respond directly or indirectly.

The non-conventional political participation of the Pulang Pisau District community in the 2013 Pemilukada was based on attitudes and actions that tended to be sporadic, consisting of the following matters.

\section{Participation in mass mobilization}

The political participation of the Pulang Pisau Regency's community in terms of participation in mass mobilization was seen to be quite large. This can be seen based on the research sample data as the following table.

Table -10: Non-Conventional Political Participation in Society in Participation in Mass Mobilization

\begin{tabular}{|l|c|c|c|}
\hline \multirow{2}{*}{ Description } & \multicolumn{2}{|c|}{ Answer } & \multirow{2}{*}{ Total } \\
\cline { 2 - 3 } & Yes & No & \\
\hline Total (respondents) & 46 & 26 & 72 \\
\hline Persentage (\%) & 63.89 & 36.11 & 100.00 \\
\hline
\end{tabular}

Based on this table it can be seen that the majority of respondents participated in mass mobilization in the framework of the implementation of the 2013 General Election, as many as 46 people $(63.89 \%)$. This illustrates that most people are willing to participate in activities that involve large groups of people.

\section{Engage in the Division of Political Groups Based on Candidate Pairs \\ Community participation in the General} Election is reviewed based on involving themselves in the division of political camps based on the pair of candidates is low, where the community in general is less interested in responding to the General Election with such actions. Based on the opinion of research respondents, the data obtained as the following table.
Table-11: Non-Conventional Political Community Participation in Involving Themselves in the Division of Political Groups Based on Candidate Pairs

\begin{tabular}{|l|c|c|c|}
\hline \multirow{2}{*}{ Description } & \multicolumn{2}{|c|}{ Answer } & \multirow{2}{*}{ Total } \\
\cline { 2 - 3 } & Yes & No & \\
\hline Total (respondents) & 27 & 45 & 72 \\
\hline Persentage (\%) & 37.50 & 62.50 & 100.00 \\
\hline
\end{tabular}

Based on this table, it can be seen that the majority of respondents did not involve themselves in the division of political camps based on pairs of candidates in the framework of the implementation of the 2013 General Election, as many as 45 people $(62.50 \%)$. This illustrates that most people only understand that the exercise of voting rights is felt to be sufficient to represent their attitude in favor of the candidate pair in the General Election.

\section{Statement of Attitude through Demonstration at the General Election \\ Community participation in Pemilukada is} reviewed based on the statement of attitude through demonstrations at the Pemilukada showing a very low role, where most people do not have an interest in participating in the demonstration to express their opinions and statement of attitude. Based on the opinion of the research respondents, the data obtained as the following table:

Table-12: Non-Conventional Political Participation of Society in Statement of Attitude through Demonstrations in Regional Head Elections

\begin{tabular}{|l|c|c|c|}
\hline \multirow{2}{*}{ Description } & \multicolumn{2}{|c|}{ Answer } & \multirow{2}{*}{ Total } \\
\cline { 2 - 3 } & Yes & No & \\
\hline Total (respondents) & 3 & 69 & 72 \\
\hline Persentage (\%) & 4.17 & 95.83 & 100.00 \\
\hline
\end{tabular}

Based on this table it can be seen that the majority of respondents did not participate in the statement of attitudes through demonstrations at the 2013 General Election, as many as 69 people $(95.83 \%)$. This illustrates that most people do not have the interest and interest to express opinions in the form of statements of attitude through demonstrations. For the community these actions are felt to be of little direct benefit to themselves as well as to their neighborhood.

Expressing dislike on social media regarding the implementation of the General Election of Regional Head of Regional Head in Pulang Pisau Regency

Community participation in the post-conflict local election was reviewed based on expressing dislike on social media about the implementation of the postconflict local election in Pulang Pisau Regency as a role in addressing the 2013 post-conflict local election implementation by expressing opinions and opinions through social media. Based on the opinion of research respondents, the data obtained as the following table. 
Table-13: Non-Conventional Public Political Participation in Expressing Dislike on Social Media on the Implementation of Pemilukada in Pulang Pisau Regency

\begin{tabular}{|l|c|c|c|}
\hline \multirow{2}{*}{ Description } & \multicolumn{2}{|c|}{ Answer } & \multirow{2}{*}{ Total } \\
\cline { 2 - 3 } & Yes & No & \\
\hline Total (respondents) & 44 & 28 & 72 \\
\hline Persentage (\%) & 61.11 & 38.89 & 100.00 \\
\hline
\end{tabular}

Based on the table it can be seen that the majority of respondents gave a role in the implementation of the 2013 General Election by expressing dislike on social media about the implementation of the post-conflict local election in Pulang Pisa, as many as 44 people $(61.11 \%)$. This illustrates that social media is felt to be very effective and easy to use by community members, so that the community is encouraged to express their opinions regarding the implementation of the 2013 Local Leaders Election.

\section{Antipathy to Specific Candidate Pairs so that They Have to Express Opinion to Others Directly or Indirectly}

Community participation in the General Election is reviewed based on antipathy to certain pairs of candidates so that they have to express opinions to others directly or indirectly, is a personal attitude regarding the candidate pairs who are participants in the Pemilukada in Pulang Pisau Regency. Based on the opinion of the research respondents, the data obtained as the following table:

Table-14: Non-Conventional Political Participation in Antipasti in Certain Candidate Pairs so that They Have to Express Opinion to Others Directly or Indirectly

\begin{tabular}{|l|c|c|c|}
\hline \multirow{2}{*}{ Description } & \multicolumn{2}{|c|}{ Answer } & \multirow{2}{*}{ Total } \\
\cline { 2 - 3 } & Yes & No & \\
\hline Total (respondents) & 61 & 11 & 72 \\
\hline Persentage (\%) & 84.72 & 15.28 & 100.00 \\
\hline
\end{tabular}

Based on this table it can be seen that the majority of respondents expressed their antipathy by expressing opinions to others regarding certain pairs of candidates in the implementation of the 2013 General Election, as many as 61 people $(84.72 \%)$.

\section{CONCLUSION}

The political participation of the community in the post-conflict local election in Pulang Pisau District in 2013 was influenced by three factors; individual, social, and behavioral characteristics. Individual characteristic factors have a very high relationship category with political participation in the community in the Pulang Pisau District Election process. This shows that the individual characteristics of the community have a very strong influence on the political participation of the community, so the first research hypothesis can be accepted. Social characteristics factor has a high category of relationship with political participation in the community in the Pulang Pisau District Election process. This shows that the social characteristics of the community have a very strong contribution to the political participation of the community, so that the second research hypothesis can be accepted. Election behavior factors have a sufficient relationship category with political participation in society in the Pulang Pisau District Election process. This shows that the voting behavior of the community has a strong enough contribution to the political participation of the community, so that the third research hypothesis can be accepted. Political participation in the Pulang Pisau Regency community in the 2013 Pemilukada was stated based on the results of the research respondents' answers, to illustrate the conventional and unconventional political participation of the Pulang Pisau Regency community in the 2013 Local Leaders Election.

\section{REFERENCES}

1. Al-Iman, A. N. (2004). Membongkar Dosa-dosa Pemilu. Prisma Media: Jakarta.

2. Mustafa, D. (2013). Birokrasi Pemerintahan. Cet 1. Bandung: Alfabeta.

3. Huda, S. (2014). Partisipasi Politik Masyarakat Dalam Pemilukada 2012 Kabupaten Pati (Studi Kasus Di Desa Tegalharjo Kecamatan Trangkil Kabupaten Pati).

4. Sugiyono. (2012). Metode Penelitian Kuantitatif, Kualitatif Dan R\&D. Bandung: Alfabeta.

5. Arikunto, S. (2004). Prosedur Penelitian Suatu Pendekatan Praktek, Edisi Kelima. Jakarta: Rineka Cipta.

6. Sugiyono. (2016). Metode Penelitian Manajemen. Bandung: Alfabeta.

7. Dahl, R. A. (1971). Polyarchy: participation and Opposition. Yale University Press: New Haven.

8. Denhardt, R. (1984). Theories of Public Organization. Monterey, CA: Brooks/Cole Publishing Company.

9. O'Connell, B. (1999). Civil Society: The Underpinnings of American Democracy. Tuffs University: London.

10. Undang - Undang Dasar Republik Indonesia Tahun 1945 pasal 28. 